\title{
Czy nauczycielowi w XVI-wiecznej Polsce żyło się dobrze?
}

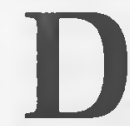
la szlachcica żyjącego w XVI w. wykształcenie było ważnym, ale nie najistotniejszym składnikiem jego egzystencji w swoim środowisku. Za wykształconego uchodził ten człowiek, który spędził trochę czasu w szkole, na dworze magnackim (szkole pałacowej). Następnie udał się clo jakiegoś ośrodka akademickiego w kraju lub za granicą, a zdobytą wiedzę spożytkował w służbie publicznej, na dworze królewskim, kancelariach magnatów świeckich i duchownych lub instytucjach samorządów miejskich czy sądach. Niektórzy badacze do wyżej wymienionych kryteriów zaliczają też umiejętność przelania zdobytej wiedzy na papier, która przetrwała w postaci listów, twórczości własnej, opiniach współczesnych, zainteresowaniach bibliofilskich czy mecenacie ${ }^{1}$.

Wiedza szlachty miała charakter utylitarny. Do szkół uczęszczały dzieci w celu zdobycia umiejętności, które przydać by się mogły w przyszłym życiu codziennym, publicznym. Tych, którzy ich nie posiadali, określano mianem prostaków. Tak więc w powszechnym wówczas odczuciu pana można było poznać nie tylko po cholewach i manierach, ale także po sposobie wysławiania się, znajomości liter i umiejętności posługiwania się nimi. Piszacy w XVII w. Nekanda Trepka nowych szlachciców nazywał prostakami i icliotami, ponieważ często nie potrafili pisać i czytać. „I tak Błękicki od Torunia chłopski syn idyjota nie umie czytać ani pisać" czy Bronicki Jordan „iclyiota ni pisać ni czytać nie umie”2. W środowisku żydowskim mężczyzna, który nie potrafił czytać, uchodził za kalekę. Tak więc dla chudopachołków sposobem na zatuszowanie swojego niskiego pochodzenia była szkoła, która potrafiła zmienić wyglącl i wnętrze człowieka.

Dostęp do szkół w XVI-wiecznej Polsce nie był trudny, zwłaszcza dla synów szlacheckich. Do posyłania do szkól także synów mieszczańskich i chlopskich nawoływali ówcześni pisarze i politycy, bezpośrednio zaangażowani w reformy ruchu egzekucyjnyego lub czynnie je popierający. Mikołaj Siennicki tłunaczył na sejmie $1565 \mathrm{r}$., że duchowieństwo uzyskało dlatego tak dużo przywilejów, gdyż mogło wykazać się znajomością czytania i pisania. Marcin Kromer, Erazm Gliczner, Szymon Marycjusz podkreślali korzyści płynące $z$ wysyłania dzieci do szkól ${ }^{3}$. Dzięki sprzyjającej atmosferze intelelstualnej i dobrej sytuacji gospodarczej dzieci pochodzenia plebejskiego równiez trafiały clo róznych typów ówczesnych instytucji oświatowych i stanowiły w drugiej połowie XVI w. przeszło połowę słuchaczy Alrademii Krakowskiej. Synowie chłopscy zaś stanowili 10\% tam studiujacych ${ }^{4}$.W XVII w. podane proporcje uległy zmianie na niekorzyść stanów uboższych. Studentów Akaclemii zaczęły odbierać kolegia jezuickie i szkoły protestanckie, pomimo akcji stypendialnej, prowadzonej na szeroką skalę głównie przez profesorów krakowskiej Alma Mater. 
Edukacja więlkszej części spoleczeństwa staropolskiego zaczynała się od szlkoły parafialnej. Według badan E. Wiśniowskiego szkoły takie istniały w $90 \%$ parafii działających w Małopolsce i Wielkopolsce ${ }^{5}$. W tych szkołach - funkcjonujących w miastach i miasteczkach - nauczali byli jej absolwenci, aktualnie pełniący funkcje pisarzy miejskich, urzędników magistrackich, czasem tė̇ studenci. W szkołach wiejskich kwalifikacje nauczycielskie tylko trochę przewyzszały umiejętności wychowanków, chociaż zdarzały się wyjątki. Tak więc ówcześni nauczyciele to ludzie o plebejskim rodowodzie. Efekty nauki plebejów są nie zawsze łatwo i bezpośrednio uchwytne w materiale źródlowym ze względu na chęć zatuszowania ich niskiego pochodzenia. Jak pokazują dotychczasowe badania najwięcej „wyedukowanych" chłopów miały dwie małopolskie wsie - Jodłowa i Jadowniki. Były to wsie bogate, $z$ zachowaną dokumentacją sporządzoną przez jej mieszkańców, zasiadających w ławach miejscowego sąlu w charakterze pisarzy wiejskich. Fenomen ten polegal m.in. na tym, że w XVI w. kancelarię sąclów ławniczych wiejskich zazwyczaj obsługiwał pisarz ,importowany" $z$ pobliskiego miasta ${ }^{6}$. Tutaj zaś było inaczej. Do szkół w tych obu wsiach chodziło najwięcej miejscowych chłopców. Spośród jej mieszkańców, absolwentów szkoły parafialnej, rekrutowało się najwięcej jadowickiego kleru, nauczycieli, przedmieszczan, a po latach obywateli okolicznych miast - Biecza, Bochni, Krakowa ${ }^{7}$. Przykładem najbardziej spektakularnej kariery w XVI w. jest Klemens Janicki, syn chłopa wielkopolskiego, który - zauważony przez miejscowego nauczyciela i odpowiednio przez niego pokierowany - ukończyl Akademię Krakowską, a następnie kształcił się we Włoszech. Po powrocie trafił na dwór arcybiskupa Andrzeja Krzyckiego i przebywał na nim jako sekretarz jego kancelarii.

Nauczyciel szkoły parafialnej nie cieszył się ani specjalnym szacunkiem, ani zaufaniem społecznym, był też źle wynagradzany. Na wsiach podporzadkowano nauczycieli proboszczom i traktowano na równi ze służbą kościelną ${ }^{8}$. Kwalifikacje nauczycieli były przedmiotem obrad synodów katolickich. W $1510 \mathrm{r}$. synod piotrkowski zalecił, że nauczycielani mogą być mężczyźni, którzy poddadzą się odpowiednim egzaminom ${ }^{9}$. Pierwsze egzaminy, których efekty opublikowano po latach, przeprowadzono w diecezji krakowskiej w czasie rządów Franciszka Krasińskiego, czyli w drugiej połowie XVI w. Pozostałością owych sprawclzianów są księgi egzaminowanych ${ }^{10}$. W 1527 r. na synodzie łęczyckim ogłoszono, ze nauczyciel szkoły parafialnej powinien mieć chociaż bakalaureat, a nauczający w szkole kolegiackiej czy katedralnej - magisterium ${ }^{11}$. Niewątpliwie troska o wyższy poziom kształcenia w szkołach katolickich wynikała $z$ rozszerzania się protestantyzmu. W rzeczywistości w większości szkół od nauczycieli wymagano jedynie złożenia wyznania wiary zgodnego $z$ profilem wyznaniowym szkoły, w której ubiegał się o pracę. Z drugiej polowy XVI w. pochodzą potrydenckie wizytacje polskich diecezji. Z opublikowanych przez M. Wojtasa akt wizytacji dekanatów bytomskiego i pszczyńskiego, dokonanych z polecenia kardynala Jerzego Radziwiłła, wynika, że na tych terenach szkoły były we wszystkich wizytowanych parafiach miejskich i w większych wsiach. Nauczyciel, nazywany w źróclle rektorem, mieszkał w osobnym budynku, w którym odbywały się zajęcia szkolne. Do dyspozycji nauczającego pozostawał ogród i kawałek ziemi uprawnej ${ }^{12}$. Źródła milczą na temat opłat uiszczanych przez 
uczniów na rzecz nauczyciela. Nie były to bowiem kwoty płacone $z$ kasy parafii, a więc wizytatorów nie interesowały.

Spójrzmy na pozycję nauczyciela w społeczeństwie staropolskim oczami mu współczesnych. Pewien obraz jego sytuacji materialnej uzyskamy zagląclając do XVI-wiecznych tabel podatkowych, tzw. rejestrów pogłównego. Podlatek ten był uchwalany przez sejn w sytuacjach szczególnych i obejmował wszystkie stany spoleczne, grupy zawodowe i wiekowe (uwzględnial dzieci, które ukończyły 10 rok życia i według ówczesnych pojęć miały szansę na dalsze życie). Dawal więc w miarę pełny obraz możliwośći finansowych spoleczeństwa polskiego. Twórcy tabel dochodu doskonale wiedzieli ile kto jest w stanie zapłacic podatku od uzyskiwanych przez siebie dochodów. Tak więc ustawiano próg podatkowy, ażeby mógł on odzwierciedlać nie tylko dochócl, czyli zamożność podatnika, ale i jego prestiż społeczny. Pogłówne było uchwalone w XVI w. dwukrotnie: po raz pierwszy w 1520 r. oraz w 1590 r. Nauczyciele szkół parafialnych według taryfy z 1520 r. płacili od 4 do 12 groszy, a w 1590 r - od 4 do 24 groszy. Była to najniższa stawka podatkowa. Oczywiście więcej pieniędzy odprowadzał do kasy państwowej bakałarz $z$ dużego miasta, mniej $z$ mniejszego, tylko na 4 grosze wyceniono możliwości podatkowe nauczających w wiejskich szkołach parafialnych. Potraktowano ich na równi ze studentami, służbą zamkową i dworską oraz robotnikami wykwalifikowanymi. Według ówczesnej stratyfikacji ludności wiejskiej status nauczyciela odpowiadał pozycji zagrodnika, a więc niezamożnego chłopa ${ }^{13}$. Tak więc uposażenie $w$ pieniądzu nauczycieli wiejskich szkól parafialnych można porównywać z zarobkami niektórych pracowników najemnych, zatrudnianych wówczas na folwarkach małopolskich (urzędnika, dwornika, parobka $)^{14}$. Z tego porównania wypływa wniosek, że $z$ punktu wiclzenia ówczesnych ludzi prestiz społeczny urzędnika administrującego folwarkiem czy stojącego niżej w strukturze urzędów wiejslkich - dwornika, był znacznie wyższy niż nauczyciela, mimo że dochody tych kategorii zawodowych były podobne. To właśnie $z$ takich wzbogaconych urzędnikow wiejskich rekrutowała się pseudoszlachta, którą z właściwym sobie zacietrzewieniem ścigał w XVII w. wspomniany wcześniej Trepka. Status nauczyciela szkoły parafialnej w mieście był tożsamy $z$ wiejskim.

W tej sytuacji nie należy się dziwić, że nauczyciele, aby poprawić swój stan materialny, poszukiwali dodatkowych źródeł dochodu. Czasami dorabiali biorąc posady pisarzy wiejskich, o czym wspominano wyżej, niekiedy starali się o dodatkową pracę w urzędlach miejskich. Wójt miasta Bielska na Mazowszu zawarł kontrakt $z$ nauczycielem parafialnej szkoły zakroczymskiej na pisarza ${ }^{15}$. W Krakowie, jak zauważył W. Urban, źródlem dodatkowych clochodów nauczających były prywatne lekcje udzielane wdowom po rzemieślnikach oraz zatrudnianie się w charakterze prywatnych nauczycieli do dzieci nie uczęszczających do krakowskich szkółek ${ }^{16}$. Znane są rozliczne przypadki nauczycieli dorabiających przy kopiowaniu ksiąg. Czy było to zajęcie dochodowe? W świetle informacji, którymi dysponuję, trudno jest na to pytanie odpowiedzieć. Na pewno jednak bylo ptrzebne.

Niekiedy wladze miejskie pozwalały nauczycielom na clzierżawę sklepów w okolicach rynku aby mogli uzupełnić skromne zarobki nauczycielskie. Pensja powołanego w 1612 r. profesora języka greckiego na Akademii Krakowskiej 
była nizsza od wypłacanego w tym samym czasie stypendium studenckiego, a władze uczelni pozwalały zatrudnionym wykładowcom na korzystanie ze wszystkich wcześniej opisywanych sposobów pomnażania dochodów własnych. Zmuszony do dodatkowej pracy był zwłaszcza bakałarz obarczony rockziną. Owczesne bowiem prawo zezwalało żonatym na podejmowanie pracy w szkole. Możliwości dodatkowego zarobkowania dotyczyły elity nauczycielskiej. A jak to wyglądało na dole?

Istniało lokalne zróżnicowanie pensji nauczycielskich wszystkich typów szkół. Według danych opublikowanych przez J. Kowalika dla Sądecczyzny, uposażenie nauczyciela w pieniądzu wynosiło w XVI w. zaledwie od 2 do 5 złotych rocznie, ale do jego dochodów doliczano 1/3 dochodów lokalnego kościoła, wpływy $z$ kolędy i mesznego ${ }^{17}$. Podobne pensje otrzymywali nauczyciele we wspominanych wsiach dekanatu bytomskiego i pszczyńskiego, takze na Pomorzu. Należało by w przyszłości podjąć badania, pokazujące zróżnicowani płac tej kategorii zawodowej na obszarze całej Rzeczypospolitej, istnieją bowiem odpowiednie ku temu materiały .

Żródla, $z$ których korzystam, w niewielkim stopniu pokazują warsztat pracy XVI-wiecznych nauczycieli parafialnych. Inwentarze i wizytacje wymieniaja bowiem książki należące do parafii, ale nie znamy zasad, na jakich nauczyciel mógł $z$ nich korzystać. $Z$ akt wizytacji delkanatu bytomskiego i pszczyńskiego wynika, że biblioteki parafialne dysponowały książkami niezbędnymi do odprawiania liturgii i prowadzenia działalności duszpasterskiej, pozostawały jednak w dyspozycji miejscowego proboszcza. W parafiach tych dekanatów na parafię przypadało od 2 do 6 książek. Wizytatorzy wymieniają głównie po kilka egzemplarzy papierowych mszałów, postylli, Biblii i antyfonarzy ${ }^{18}$. Nie były to typowe podręczniki, ale na nich mógł się opierać nauczyciel pracujący $z$ miejscowymi chłopcami. Więcej o bibliotekach bakałarzy można by się dowiedzieć z zachowanych testamentów lub inwentarzy majątku ruchomego, zapisanych w sądach grodzkich.

Szkoły parafialne uczyły czytać i pisać w języku łacińskim, katechizmu, śpjewu pieśni religijnych, którymi uczniowie uatrakcyjniali nabożeństwa i uroczystości religijne. Dlatego obok nauczyciela w szkole potrzebny był kantor, $z$ którym nauczyciel musiał niekiedy dzielić dochody. Poziom miejskich szlkół parafialnych byl podobny do wiejskich, chociaż program ich był nieco rozszerzony w stosunku do szkół wiejskich o naukę rachunków, potrzebnych kupcom i rzemieślnikom, język polski, muzykę, a w najlepszych - naukę obliczania świąt kościelnych i układania kaledarza ${ }^{19}$.

W miastach obok szkół parafialnych funkcjonowały prowadzone na wysokim poziomie szkoły katedralne, kolegiackie (Płock, Włocławek, Pułtusk) i kolegia (protestanckie i jezuickie) w Gdańsku, Toruniu, Elblągu, Kaliszu, Krakowie że wymienię tylko najważniejsze. Nasuwa się pytanie o efekty owej eclukacji, czyli o znajomość czytania i pisania w społeczeństwie polskim XVI w. Próba odpowiedzi jest trudna i wynika głównie $z$ braku odpowiednich żródeł. Istnieją pewne dane dla Małopolski i clotyczą wylącznie szlachty. Wynika z nich, że na 799 zeznań podatkowych $z$ lat 1563-1565 aż 458 jest własnoręcznie podpisanych przez szlachciców, co dowodzi, że 57\% ówczesnych podatników umiało posługiwać się piórem przynajmniej na poziomie elementarnym ${ }^{20}$. Istniało oczywiście 
zróżnicowanie owych umiejętności w obrębie stanu szlacheckiego. Wyższym stopniem alfabetyzacji charakteryzowała się magnateria i bogata szlachta, nizszym uboga. Podobnie wyniki uzyliali badacze w grupie szlachty powiatu grabowieckiego na terenie poludniowej Lubelszczyzny ${ }^{21}$.

A jak przedstawiał się ten problem w miastach? Z badań W. Urbana wynika, że w interesującym nas okresie w zachodniej Małopolsce umiało pisać 71-84\% zamożnych mieszczan i 36\% mieszczek ${ }^{22}$. Najwięcej Polaków umiało czytać i pisać w połowie XVII w. Potem nastąpował spadek, trwający aż do XIX w. W zachodniej Europie obserwuje się w tym czasie tendencję odwrotną.

$\mathrm{W}$ wiejskich szkołach parafialnych uczyło się niewielu uczniów. Z danych pochodzacych $z$ wizytacji dekanatu bytomskiego i pszczyńskiego pojawiają się informacje o 4-5 osobach uczęszczających na zajęcia szkolne. W stosunku do liczby mieszkańców był to odsetek niewielki. Absolwenci tych szkół - clzieci chłopskie i ubogiej szlachty - zostawali na wsi, otrzymując posady urzęchników folwarcznych, nauczycieli, wikarych czy plebanów. Tylko nieliczni spośrod nich kontynuowali naukę w różnych typach szkół miejskich bądź na uniwersytetach na terenie Rzeczypospolitej lub poza jej granicami. W miastach odsetek uczących się był znacznie wyższy i nie podlegał tak dużym sezonowym wahaniom, jak na wsi.

Dobra edukacja sporo kosztowała. Piotr Prendota, wojewoda rawski, musiał sprzedać dwie wsie, Boguszyce Małe i Wolę Bogucką, za 1200 złotych węgierskich - prawdopodobnie po to, aby opłacić naukę swoich synów ${ }^{23}$. Nie ma pełnych badań pokazujących rzeczywiste koszty edukacji młodych ludzi, co jest wynikiem braku materiałów źródłowych. Po grupie chłopskiej nie zachowały się żadne rachunki, jedynie wzmianki, iż taki to a taki syn chłopski uczęszczał do szkoły i może skorzystać ze stypendium. Albo odwrotnie. Fundacje stypendialne wymieniały ogólne zasady, na jakich można było ubiegać się o finansowanie kosztów kształcenia. Najwięcej danych na ten temat zachowało się w archiwach bogatej szlachty i magnatów. Nie dają one jednak pełnego obrazu ponoszonych przez rodzicow kosztow edukacji, a jedynie pewne barclzo okrojone szacunki. Są na przylkład znane wydlatki poniesione przez rodziców Stanisława Tarły, Jasia Ługowskiego, Stanisława Lubomirskiego, Stanisława Kryskiego, czy Radziwiłłów ${ }^{24}$. Na podstawie tych przylkładów historycy określili je jako wysokie. Obejmowały one zazwyczaj tylko koszty pobytu za granicą. A przecież nauka rozpoczynała się w kraju i zaczynała się od zatrudnienia nauczyciela, który musiał nauczyć łaciny klasycznej, pođstaw języlków obcych, komentowania dzieł starożytnych i modnych humanistów, retoryki, może filozofii - w zależności od wymagań rodziców i umiejętności samego nauczyciela. Z opublikowanego przez L. Kieniewicza diariusza szwajcarskiego nauczyciela Henryka Wolfa $z$ Zurychu, przebywającego w charalkterze nauczyciela i wychowawcy syna Piotra Firleja, wyłania się clość ponury obraz życia bakałarza na clworze magnata polskiego w latach siedenckiesiątych XVI w. Odrzucając subiektywizm, który towarzyszy zwykle tego typu informacjom, widziny młodego człowieka, od którego wymagano dużo, dając niewielkie wynagrodzenie i nie okazując jakiegokolwiek szacunku wobec jego pracy. Kazano mu siadać do stołu ze służbą, a nawet pewnego dnia Wielmożna Pani Wojewodzina „przyzwała mnie do siebie i w najostrzejszych slowach na mnie powstała, nazywając 
mnie wieprzem niemieckim, psem, smrodem i że nie jestem chrześcijaninem. Groziła też, że obije mnie laską. Odpowiedziałem jej w uprzejmych słowach i odszedłem"25. Wolf nie zabawił długo w Polsce i opuścił ją z radością, wywożąc nie najlepsze wrażenia o swoim chlebodawcy i jego rodzinie. Pozostawił jednak w prowadzonym przez siebie dzienniku mnóstwo trafnych obserwacji o Polakach i ich życiu codziennym. Mimo lekceważącego stosunku szlachty do nauczycieli większość rodziców zabiegala o dobrych preceptorów dla swoich synów.

W Rzeczypospolitej XVI w. istniało grono zawodowych nauczycieli - można ich nazwać guwernerami - o których zabiegala ówczesna elita polityczna. O niektórych pozostały dokładne informacje. Historycy sporo wiedzą o nauczycielach władców Polski, ale nie tylko. Nauczycielem Jana Bonera był Eforyn. Piotrem Czernym z Witowic opiekował się Wojciech z Kalisza. Łukaszowi Górce pomagał w nauce Jan z Koźmina i Eustachy Trepka. Krzysztofa Komorowskiego z Zywca nauczał znany kartograf - Waclaw Grodecki. Jan Komorowski swoich synów kształcił pod kierunkiem Mikołaja Śmieszkowica. Historyk Jan Łasicki uczył Andrzeja Krotoskiego, następnie Gnojeńskich i młodych Tarnowskich. Stanisława Gostomskiego przygotowywał do dorosłego życia znany szerszym kręgom szlacheckim nauczyciel Stanisław Jarzyna. Oczywiście większość dzieci szlacheckich miała anonimowych nauczycieli. Informacje o ich przygotowaniu zawodowym i dyclaktycznym rzadko clocierają do historyków, chyba że są to nauczyciele elity lub tacy, którzy poprzez swoje książki przechodzą do historii. Znacznie więcej wiemy o bakałarzach pracujących w XVIwiecznych kolegiach. Przy niechętnym stosunku szlachty do szkół parafialnych oczywiste wydaje się poszukiwanie dobrych nauczycieli dla swoich synów (a może i córek), którzy przygotowaliby szlachecką latorośl do szkoły wyższego typu.

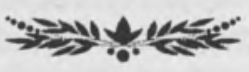

\section{Przypisy:}

${ }^{1}$ M. Chachaj, Wykształcenie świeckich senatorów w Wielkim Księstwie Litewskim za panowania Zygmunta III Wazy, „Acta Universitatis Wratislaviensis”, nr 66 (945), Wroclaw 1988 , s. 258.

${ }^{2}$ W. Nekanda-Trepka, Liber generationis plebeanorum, (oprac.) R. Leszczyński, (wyd.), 2, Wrocław-Warszawa-Kraków 1995, s.77, 89.

${ }^{3}$ S. Olczak, Szkolnictwo parafialne $w$ Wielkopolsce $w$ XVII-XVIII wieku $w$ świetle wizytacji kościelnych, Lublin 1978, s. 42.

${ }^{4}$ I. Kaniewska, R. Żelewski, w: W. Urban, Studia z dziejów mlodzieży Uniwersytetu Krakowskiego w dobie Renesansu, (red.), K. Lepszy. Kraków 1964, s. 9.

${ }^{5}$ S. Olczak, Szkolnictwo parafialne..., s. 41.

${ }^{6}$ A. Kamler, Praca najemna na wsi małopolskiej w XVI i pierwszej polowie XVII wieku, „Kwartalnik Historyczny”, t. XCVII, 1990, nr 1-2, zob. Księga sądowa wiejska wsi Iwkowa. 
${ }^{7}$ Z. Pietrzyk, Wyksztalceni synowie chłopscy w Małopolsce w okresie późnego odrodzenia, Kraków 1993, s. 76 i nn.

${ }^{8}$ Ibidem, s. 117.

${ }^{9}$ J. Ryś, Szlsolnictwo parafialne w miastach Malopolski w XV wieku, Warszawa 1995, S. 31 .

${ }^{10}$ Z. Pietrzyk, Ksieggi egzaminów do święceń w diecezji krakowskiej z lat 1573-1614, Kraków 1991.

${ }^{11} \mathrm{~J}$. Ryś, Szkolnictwo parafialne..., s. 32 i nn.

${ }^{12}$ Akta wizytacji dekanatów bytonnskiego i pszczyńskiego dokonanej w roku 1598 $z$ polecenia Jerzego kardynała Radziwilla biskupa krakowskiego, (wyd.) M. Wojtas, Katowice 1938.

${ }^{13}$ A. Wyczański, Uwarstwienie społeczne w Polsce XVT wieku. Studia, Wrocław 1977, s. 234.

${ }^{14}$ A. Kamler, Wynagrodzenie pracowników najemnych, „Przegląd Historyczny”, t. LXXXI, 1990, z. 3-4, s. 662.

${ }^{15}$ A. Bartoszewicz, Mieszczanie "litterati” w polskim mieście późnego średniowiecza, „Kwartalnik Historyczny”, R. CVI, 1999, z. 4, s. 9.

${ }^{16}$ W. Urban, Rzut oka na nauczanie domowe w Malopolsce w pierwszej polowie XVI wieku, „Roczniki Biblioteki PAN w Krakowie”, R. XXXVIII, 1993.

${ }^{17} \mathrm{~J}$. Kowalik, Szkolnictwo parafialne $w$ archidiakonacie sądeckim od XVI do XVIII wieku, Lublin 1983, s. 78.

${ }^{18}$ Akta wizytacji dekanatów..., s. 85, 93.

${ }^{19}$ D. Żołądź, Możliwości i potrzeby edukacyjne mieszczan polskich w XVI-XVII wieku, w: Rozprawy z dziejów oświaty, t. 33, 1990; J. Kowalik, Szkolnictwo parafialne..., s. 63 i nn.

${ }^{20}$ A. Wyczański, Szlachta polska XVT wieku, Warszawa 2001, s. 64. 1992.

${ }^{21}$ W. Urban, Alfabetyzacja w dawnej Polsce, „Przegląd Powszechny”, nr 6 (850),

${ }^{22}$ Ibidem, s. 454 i n.

${ }^{23}$ Polski słownik biograficzny, t. XXVIII/3, z. 118, s. 455.

${ }^{24}$ W. Czapliński, J. Długosz, Podróż młodego magnata do szkól, Warszawa 1969, zob. Wstęp i rozdz. II.

${ }^{25}$ Polskie przypadki Henryka Wolfa z Zurychu. Dziennik podróży z lat 1570-1578, (oprac.), L. Kieniewicz, Warszawa 1996, s. 79. 